\author{
Jan Zawadka ${ }^{\bowtie 1}$, Anna Ivolga ${ }^{2}$ \\ ${ }^{1}$ Warsaw University of Life Sciences WULS-SGGW \\ ${ }^{2}$ Stavropol State Agrarian University
}

\title{
Tourist popularity of Poland among the inhabitants of Stavropol Krai
}

\begin{abstract}
Summary. The article presents the tourist popularity of Poland among the inhabitants of Stavropol Krai (a region located in the south of the European part of the Russian Federation). The research attempted to identify the reasons for discouraging the inhabitants of this region to take a tourist trip to Poland. Also presented the reasons, ways of organization and opinions on the tourist attractiveness of Poland against the background of selected countries among the people who visited Poland. The survey, in the form of an internet survey, was conducted among 141 inhabitants of Stavropol Krai. Based on the results of the research it can be stated that for the inhabitants of this region Poland is an attractive tourist country. However, it must be emphasized that much is still to be done to promote Poland as an attractive tourist destination. A large part of the respondents were not aware of its tourist attractiveness, which was the main reason for the lack of interest in this country.
\end{abstract}

Key words: tourism, tourist attractiveness, Poland, Stavropol Krai, Russia

\section{Introduction}

Poland is a country of considerable tourist attractiveness. This is a result of different tourist values, which enable the practicing of numerous types and forms of tourism. The northern part of the country is a coastal area and a lakeside area, which is conducive to leisure and recreation, as well as many forms of water qualified tourism. South is dominated by mountain areas, which are visited in winter by skiers and snowboarders, and in summer by hiking and cycling enthusiasts. Roztocze is also popular in this regard as well as numerous national and landscape parks, where many paths, trails and tourist routes are marked. In addition to natural value, many visitors appreciate the anthropogenic attractions. The most popular among them are: Wawel Castle, Old Town in Warsaw, Salt Mine in Wieliczka, Teutonic Castle in Malbork and the former German Auschwitz-Birkenau Concentration Camp in Oświęcim. The rural areas and their folklore and culinary traditions also enjoy great success. Poland's considerable attractiveness is also evidenced by the fact that in 2016 it became the destination of nearly 17.5 million tourists from abroad. Most of them were traditionally Germans, but a significant group (4.6\%) were Russians ${ }^{1}$.

${ }^{1}$ Tourism in 2016. Central Statistical Office, Warsaw 2017, p. 107. 


\section{Purpose and method of research}

The purpose of this article is to present the tourist popularity of Poland among the inhabitants of Stavropol Krai (a region located in the south of the European part of the Russian Federation). The research attempted to identify the reasons for discouraging the inhabitants of this region to take a tourist trip to Poland. Also presented are: reasons, ways of organization and opinions about the attractiveness of Poland in the context of selected countries among the people who visited it. A diagnostic survey was conducted using the questionnaire survey, which was disseminated by the internet during a scientific internship conducted by the author at Stavropol State Agrarian University in August 2017. The study involved 141 residents of Stavropol Krai.

\section{The concept and essence of tourist attractiveness}

Tourist attraction is manifested by the existence of specific features, attracting tourists to specific places thanks to the values of natural landscape and climate, monuments of history and interesting tourist infrastructure ${ }^{2}$. In classic terms, tourist attractions (both natural and anthropogenic), tourist infrastructure and communication accessibility of the area are included in the basic elements that determine tourist attractiveness ${ }^{3}$. G. Gołembski defines this concept as a result of four basic elements: tourist values, the state of the environment and its purity, activities in the field of environmental protection and communication accessibility ${ }^{4}$. It can be said that the concept of tourist attractiveness integrates elements that are the basis of development of tourist traffic, that is, tourist values with the conditions necessary to meet the needs of this traffic in the form of properly planned tourist infrastructure ${ }^{5}$.

A slightly extended criteria determining the attractiveness of tourism proposed by A. Balińska, which claims that this feature is a consequence of the occurrence and often coexistence of the following elements ${ }^{6}$ :

- natural values,

- anthropogenic values (material and non-material culture);

- the state of the environment and its protection,

- tourism infrastructure and tourist services,

- communication accessibility (in the sense of movement and social communication ie information transfer).

- the relationship of the local community to outside investors and tourists.

${ }^{2}$ Z. Kruczek: Polska. Geografia atrakcji turystycznych, Proksenia, Warszawa 2002, p. 273.

${ }^{3}$ O. Rogalewski: Zagospodarowanie turystyczne, WSiP, Warszawa 1979, p. 8.

${ }^{4}$ G. Gołembski: Kompendium wiedzy o turystyce, PWN, Warszawa 2002, p. 330.

${ }^{5}$ J. Kosierewicz, K. Obodyński: Turystyka i rekreacja, Wymiary teoretyczne i praktyczne, Wydawnictwo Uniwersytetu Rzeszowskiego, Rzeszów 2006, p. 145.

${ }^{6}$ A. Balińska: Atrakcyjność turystyczna wybranych gmin wiejskich Podlasia w opinii turystów, [in:] A. Balińska (ed.), Potencjał turystyczny regionów, Wydawnictwo FAPA, Warszawa 2009, p. 34. 
It is worth mentioning that the precursors of research on tourist attractiveness emphasized its complex character and stressed the difficulties in unequivocally evaluating it. It should be noted that apart from the objectively existing conditions of the natural, cultural or social environment, psychological factors play an important role in the perception or assessment of the tourist attractiveness of a place or an object ${ }^{7}$. The importance of subjectivity in terms of tourist attractiveness and its assessment is also emphasized by many other researchers. J. Potocka notes that an area or an object can be evaluated by the prism of own tourist experiences, his beliefs and values ${ }^{8}$. M. Nowacki $(2003,2012)$ adds that the assessment of tourist attractiveness from the perspective of sensations (impressions, experience) of tourists may be more reliable as the subjective assessment criteria used in many methods are not often relevant to their preferences and expectations ${ }^{9}$. It is further noted that sociocultural resources, understood as intangible and elusive elements of experiences ad impressions of tourists affect both the effigy of the destination as well as its attractiveness in their opinion ${ }^{10}$.

To summarize the considerations concerning the attractiveness of tourism, it should also be noted that it can have a relative and universal form. In terms of universality, cultural, natural and terrain features in tourist infrastructure are useful and attractive to all visitors, while in relative terms the attractiveness of the area is assessed in relation to a particular form of tourism such as cycling, sailing or religious ${ }^{11}$.

\section{Characteristics of respondents}

The survey group consisted of 141 inhabitants of the Stavropol Krai. A significant proportion of respondents (34.0\%) were aged from 18 to 24 years. The respondents between 25 and 34 years of age were $21.3 \%$ of the study group, and between 35 and 44 were $27.7 \%$. $17.0 \%$ of respondents were from 45 to 64 years old. There were slightly more women (55.3\%). The vast majority of respondents $(89.4 \%)$ lived in the city. The research was conducted during the internship at the university hence the dominance of young and well-educated people. $61.7 \%$ of respondents were in the process of graduation or graduation. $27.0 \%$ had secondary education and the rest finished gymnasium.

\footnotetext{
${ }^{7}$ More on this topic: J. Warszyńska: Waloryzacja miejscowości z punktu widzenia atrakcyjności turystycznej (zarys metody), Prace Geograficzne Uniwersytetu Jagiellońskiego 1970, no 27; J. Warszyńska, A. Jackowski: Podstawy geografii turyzmu, Wydawnictwo Naukowe PWN, Warszawa 1978.

${ }^{8}$ J. Potocka: Atrakcyjność turystyczna i metody jej identyfikacji, [in:] Z. Młynarczyk, A. Zajadacz (ed.), Uwarunkowania i plany rozwoju turystyki. Volume III. Walory i atrakcje turystyczne. Potencjał turystyczny. Plany rozwoju turystyki, Uniwersytet Adama Mickiewicza, Poznań 2009, p. 19.

${ }^{9}$ More on this topic: M. Nowacki: Wrażenia osób zwiedzających atrakcje turystyczne, Folia Turistica 2003, no 14; M. Nowacki: Atrakcje turystyczne. Koncepcje, stan, determinanty zadowolenia osób zwiedzających, AWF, Poznań 2012.

${ }^{10} \mathrm{M}$. Zdon-Korzeniowska: Jak kształtować regionalne produkty turystyczne? Teoria i praktyka, Uniwersytet Jagielloński, Kraków 2009, p. 17.

${ }^{11}$ W. Kurek: Turystyka, Wydawnictwo Naukowe PWN, Warszawa 2007, p. 24.
} 


\section{Research results}

Among the respondents, can be distinguished two groups. The first $(59.6 \%)$ were people who were never in Poland. The most common reason for this was the lack of awareness of the tourist attractiveness of Poland resulting from the lack of proper promotion (53.6\%). Passport and visa difficulties (28.6\%), high travel costs (25.0\%), and significant distance (17.9\%) were also mentioned. Almost $11 \%$ respondents in this group identified Poland with a country lacking interesting tourist attractions, which could be a motive for tourist departure.

The second group ( $40.4 \%$ of all respondents) were people who visited Poland for tourist purposes ${ }^{12}$. They were relatively young (52.6\% were not over 34 years old), well educated (47.4\% had higher education or were at the university) and lived in cities (89.5\%).

The vast majority of respondents (84.2\%) visited Poland once, $10.5 \%$ two or three times, and $5.3 \%$ four times and more. Long-term trips dominated among the respondents $-68.4 \%$ spent 4 or more nights ( $14 \%$ at least 7$)$. The most frequently used accommodation facilities were hotels (91.2\%).

The trips were mostly self-organized (69.4\%) and also with the support of family and friends $21.1 \%$. Only $10.5 \%$ of the respondents used the travel agency services. Due to the considerable distance separating Stawropol and Poland, the majority of the respondents chose a plane as a means of transport (57.9\%). For a much longer journey by bus and car decided to respectively 26.3 and $10.5 \% .5 .3 \%$ of the respondents used the train.

Importantly, they all perceived Poland as a tourist attractive country, and $89.5 \%$ of the respondents would recommend it as a tourist destination to their family or friends ${ }^{13}$.

One of the important objectives of the study was to identify the opinions of the inhabitants of Stavropol on the attractiveness of Poland in relation to selected countries. Details on this are presented in Figure 1.

Poland's tourist attractiveness in the opinion of the respondents can be considered as significant. In a few cases it was defined as greater, and in most comparisons it was similar to other countries. It should be emphasized that many of the surveyed attractiveness of Poland was perceived equally with Turkey or Bulgaria, which are very fashionable destinations of summer trips. Puzzling is the fact that Ukraine in this respect was rated very low. The cause may be the uneasy situation currently prevailing between the two countries. The respondents rated their country very highly. Taking into account its huge area and diversification of tourist values, as well as great potential for the development of any form of tourism, this assessment should not be surprising.

The respondents were asked to express their opinion on the attractiveness of selected Polish cities. Unrivaled in this ranking were two largest cities - Cracow and Warsaw (Fig. 2). Certainly important is the fact that old towns of these two cities are included in the UNESCO World Heritage List.

\footnotetext{
${ }^{12}$ All percentages presented in the next part of the article refer only to the part of the respondents who were in Poland.

${ }^{13}$ This action can be significant, because only $31.6 \%$ of the respondents positively rated promotional activities for attractiveness of Poland on their home market.
} 


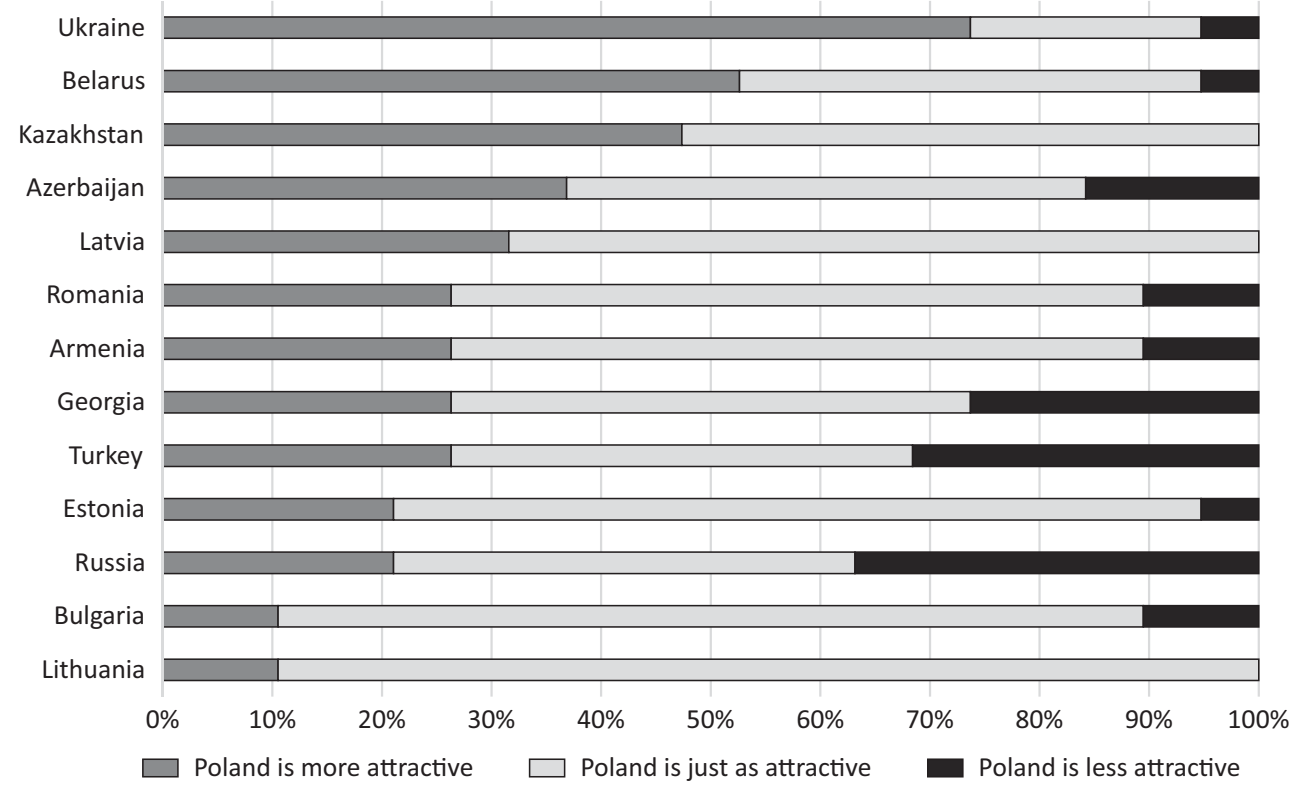

Figure 1. Tourist attractiveness of Poland on the background of selected countries in the opinion of respondents (\%)

Source: own research.

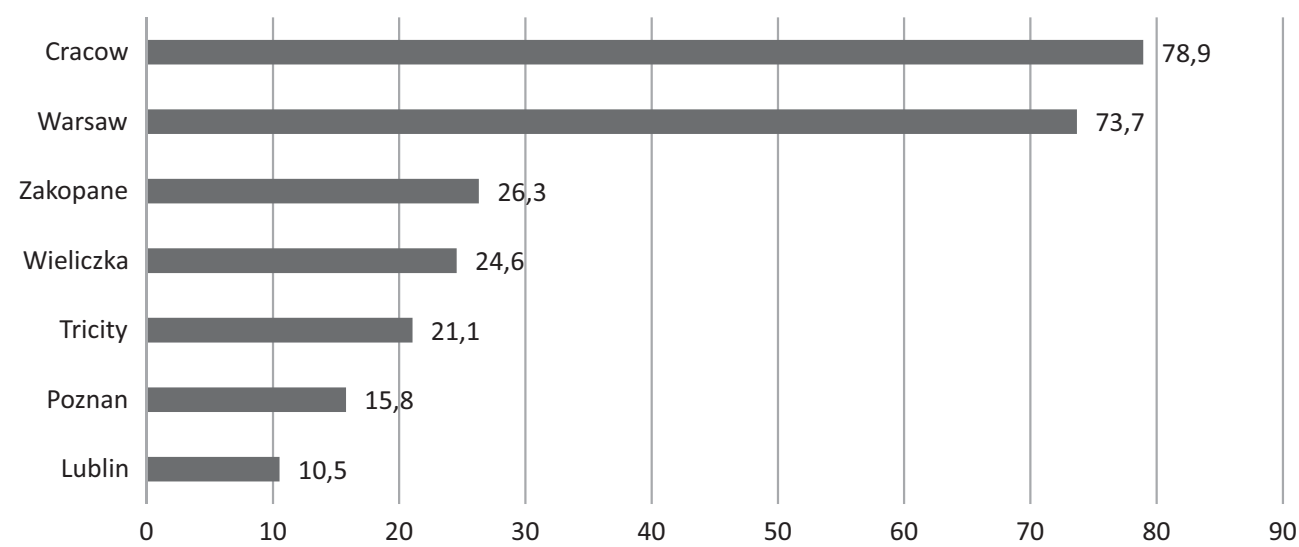

Figure 2. Attractive tourist city/places in Poland in the opinion of the respondents (the respondents could indicate more than one answer, \%)

Source: own research.

Next to it was the "winter capital of Poland" and the most popular place in the mountains, Zakopane, as well as Wieliczka with its historic salt mine, which also appears on the UNESCO list. It may be a little bit surprised that none of the other objects entered on this list was selected by the respondents. 
Preferred cities are related to the reasons that disposed the respondents to visit Poland for tourist purposes. The most often pointed out was the desire to learn Polish culture and tradition, which was stressed by almost $3 / 4$ respondents. Interesting places were also related with notable Poles. Details on this are presented in Figure 3.

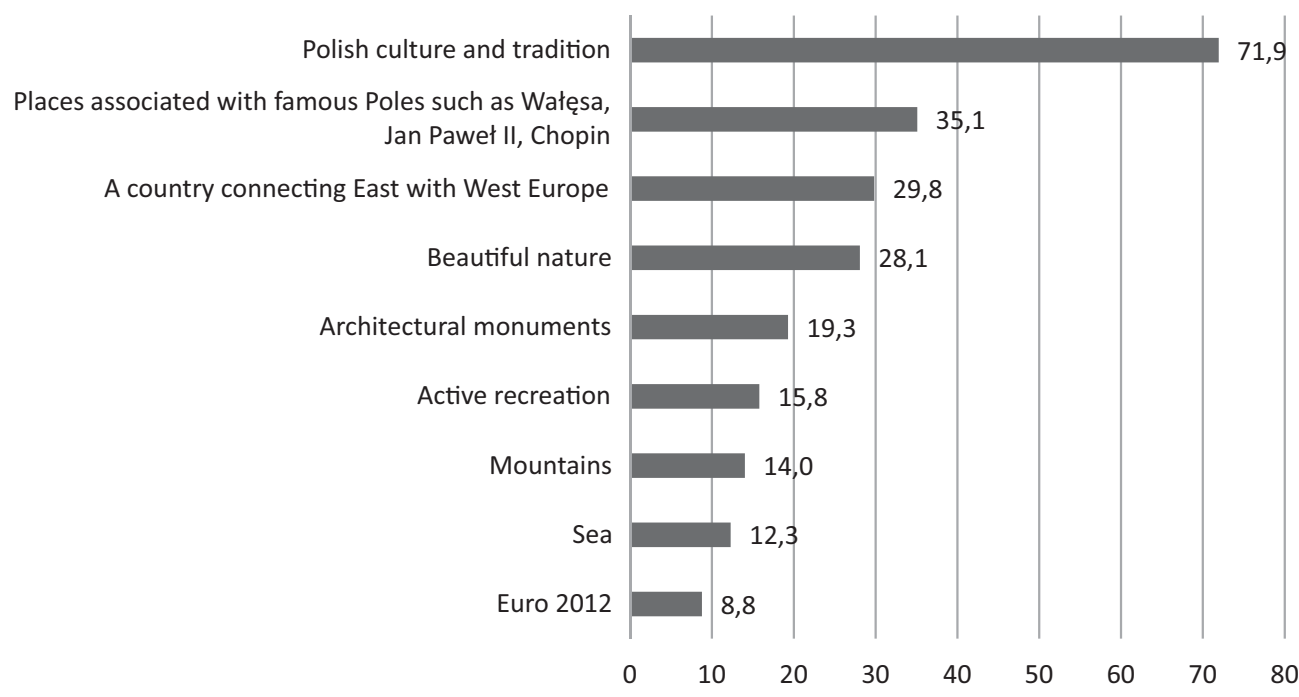

Figure 3. Reasons for respondents to visit Poland for tourist purposes (the respondents could indicate more than one answer, \%)

Source: own research.

Interestingly, the great hopes of increasing the attractiveness of Poland related to the organization of the European Football Championship in 2012 have not been confirmed by the respondents. Only less than $10 \%$ of them indicated willingness to participate in this event as an incentive to come to Poland. Also the Polish sea and mountains were not attractive to the inhabitants of Stavropol Krai. Against the backdrop of the nearby Caucasus and Black Sea, these destinations do not attract much attention.

The respondents were also asked to indicate how to spend their time in Poland. These ways were closely related to the previously discussed motives - a significant part of the respondents indicated that they preferred sightseeing and participation in cultural events, which enabled them to learn about Polish culture and traditions as well as places connected with famous Poles (Fig. 4).

Quite often, it was also a leisure, as well as spending time on shopping. Apart from the differences in prices and goods available in both countries, visits in shopping malls of large cities can be attributed to the recent fashion of such "trips" to places of this type (usually on weekends). 


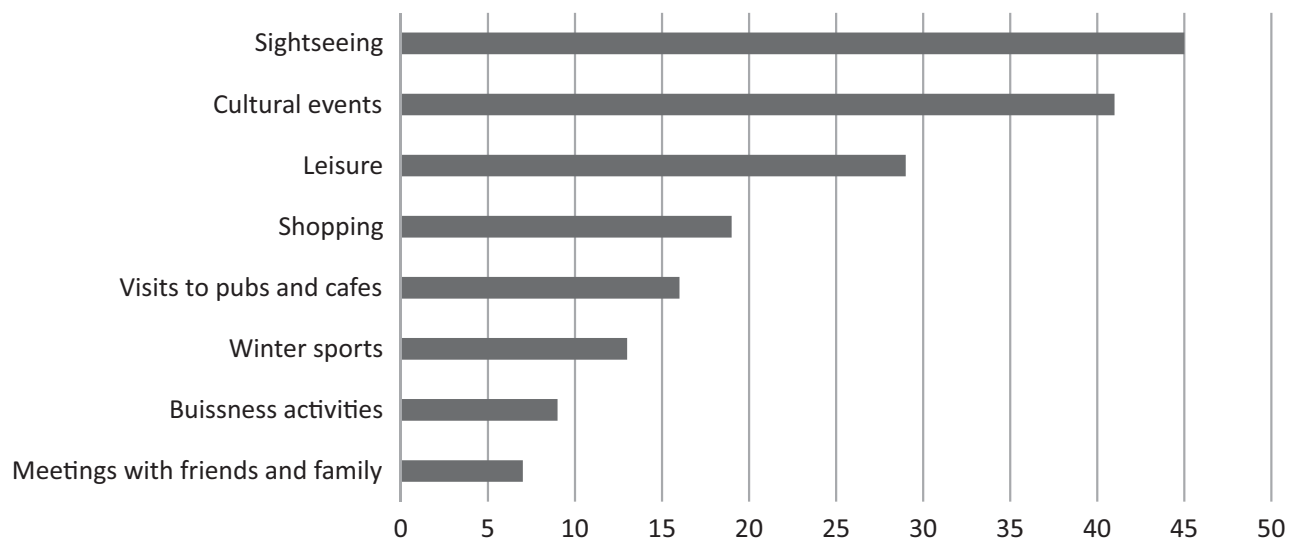

Figure 4. Preferred ways of spending time by the respondents during a tourist stay in Poland (the respondents could indicate more than one answer, \%)

Source: own research.

\section{Summary and conclusions}

A significant number of foreign tourists coming to Poland prove its tourist attractiveness. Apart from the inhabitants of neighboring countries (especially Germany), Poland is also appreciated by citizens of distant countries, such as Great Britain and even USA. Among the tourists coming to Poland, the Russians are also a significant part.

The research was carried out on a rather small group of respondents, among whom relatively young people predominated. The results of the research can not, therefore, be applied to all residents of the Stavropol Krai. Nevertheless, based on the results of the research, a few conclusions can be formulated, which will at least partially show the opinions of the inhabitants of this part of Russia on the tourist attractiveness of Poland.

The studies indicate that in the opinion of the inhabitants of Stavropol Krai, who had the opportunity to visit Poland for tourist purposes, it is an attractive tourist country. In addition, 9 out of 10 respondents would recommend it as a tourist destination to their family or friends. The most attractive cities were respondents Warsaw and Krakow. A large group also pointed to Zakopane and Wieliczka. For tourists from the southern part of Russia, the most important value was the polish culture and tradition, as well as places connected with the famous Poles.

It should be noted that the main reason why the respondents did not visit Poland for tourist purposes was the lack of awareness of its tourist attractiveness, which may be due to too weak promotion on the Russian market. Therefore, it seems appropriate to dynamize activities aimed at showing the great tourist attractiveness of Poland to potential foreign tourists and to dynamize the increase of their number. 


\section{References}

Balińska A.: Atrakcyjność turystyczna wybranych gmin wiejskich Podlasia w opinii turystów, [in:] A. Balińska (ed.), Potencjał turystyczny regionów, Wydawnictwo FAPA, Warszawa 2009.

Gołembski G.: Kompendium wiedzy o turystyce, Wydawnictwo Naukowe PWN, Warszawa 2002.

J. Warszyńska, A. Jackowski: Podstawy geografii turyzmu, Polskie Wydawnictwo Naukowe, Warszawa 1978.

Kosierewicz J., Obodyński K.: Turystyka i rekreacja. Wymiary teoretyczne i praktyczne, Wydawnictwo Uniwersytetu Rzeszowskiego, Rzeszów 2006.

Kruczek Z.: Polska. Geografia atrakcji turystycznych, Proksenia, Warszawa 2002.

Kurek W.: Turystyka, Wydawnictwo Naukowe PWN, Warszawa 2007.

Nowacki M.: Atrakcje turystyczne. Koncepcje, stan, determinanty zadowolenia osób zwiedzających, AWF, Poznań 2012.

Nowacki M.: Wrażenia osób zwiedzających atrakcje turystyczne, Folia Turistica 2003, 14.

Potocka J.: Atrakcyjność turystyczna i metody jej identyfikacji, [in:] Z. Młynarczyk (ed.), Uwarunkowania i plany rozwoju turystyki. Volume III. Walory i atrakcje turystyczne. Potencjał turystyczny. Plany rozwoju turystyki, Uniwersytet Adama Mickiewicza, Poznań 2009.

Rogalewski O.: Zagospodarowanie turystyczne, WSiP, Warszawa 1979.

Tourism in 2016. Central Statistical Office, Warsaw 2017.

Warszyńska J.: Waloryzacja miejscowości z punktu widzenia atrakcyjności turystycznej (zarys metody), Prace Geograficzne Uniwersytetu Jagiellońskiego 1970, 27.

Zdon-Korzeniowska M.: Jak kształtować regionalne produkty turystyczne? Teoria i praktyka, Uniwersytet Jagielloński, Kraków 2009. 